\title{
-The Evidence For Soybean Products As Cancer Preventive Agents
}

\section{${ }^{1}$ Mohamed E.M. Zowail, ${ }^{2}$ Hanaa F. M. Waer, ${ }^{2}$ Neamat Hanafi, ${ }^{1}$ Eman H. S. Khater and ${ }^{3}$ Hala}

\author{
A.El-mancy \\ ${ }^{1}$ Faculty of Science, Benha University. ${ }^{2}$ National Center for Radiation Research and Technology, \\ Atomic Energy Authority, Cairo. ${ }^{3}$ Faculty of science, Ain shams university
}

\begin{abstract}
Aim of the work: The evidence for specific soybean-derived compounds having a suppressive effect on carcinogenesis in animal model systems is created, the anti-carcinogenic potential of soybean was studied against colon cancer. Colon cancer has been induced by dimethylhydrazine (DMH).

Material and methods: The DMH was dissolved in physiologic saline and the animals were given subcutaneous injections once weekly for 16 weeks. The possible preventive effects of soybean on Dimethylhydrazine-induced colon tumors in male Sprague Dawley rats was investigated. Albino rats were divided into four groups. control group, control soybean powder group, DMH-treated colon cancer group and the fourth group treated with soybean powder+DMH.
\end{abstract}

Results: In the studied groups the colon was examined macroscopilly to calculate the number of polyps appeared in each colon. The histological and ultrastructural studies included the alternations in different component of the colon. The macroscopical examination showed that the group which was given the soybean alone showed no polyps. On the other hand the group that was given the carcinogenic agent alone expressed a high number of polyps. The histological and ultrastructural studies showed that colon cell structure of carcinogenic treated animal groups underwent cell proliferation, focal cell damage with certain nuclear changes, abundance of fibrous tissue and lymphocytic infiltration, while the group given soybean as a preventive agent expressing less number of colon polyps, and induced a moderate changes of different degrees. Conclusion: It is clear that soy bean component showed a good protective effect against the colon cancer.

\section{Keywords:soybean,cancer.}

\section{Introduction}

Colorectal cancer is one of the most prevalent causes of cancer death in developed countries. Colon cancer is the second most common cause of cancer related death (after lung cancer) (Jemal et al., 2004). The etiology of colon cancer is multifactorial, including familial environmental, and dietary agents. Despite several advancements in the understanding of the processes in carcinogenesis, presently available therapies, including surgery, radiation, and chemotherapeutic drugs are still limited for advanced stage colon cancer (Boursi and Arber, 2007). Nutritional intervention is another 
effective and promising complimentary strategy for controlling the incidence of colon cancer ( Hoensch and Kirch, 2005). The strong link between dietary factors and colon cancer has caused speculation that significant reduction in colon cancer incidence could be achieved through dietary modification (Levi et al., 2001). Interest in lowering colon cancer risk by dietary means has also been stimulated by an awareness that existing methods for treating colon cancer are largely ineffective. Surgery is the principal method of treatment, but the surgical success rate for patients with recently diagnosed colon cancer is less than $40 \%$ (Bond, 2000). The lack of an effective treatment has underlined the importance of developing a better understanding of the role of diet in preventing colon cancer (Chao et al., 2005). Prevention of cancer remains a primary need and new chemo preventive agents must be developed for this purpose. During the past two decades, attention has been focused on the possible role of soybeans, which contain trypsin inhibitors, isoflavones, and phytic acid on reducing or delaying the incidence of many tumors in experimental animals (Lamartiniere 2000; Su et al., 2000; Zaizen et al., 2000).

Moreover, epidemiological and animal studies suggest that diets low in animal fat and high in fruits, vegetables, grains, and legumes may protect against colon cancer. For example, diets containing soybean and soybean-based products may reduce the risk of certain types of cancer, including breast, prostate, and colon cancer (Messina et al., 1994; Hakkak et al., 2000). Investigation of Watanabe and Koessel (1993) showed lower colon cancer incidence in areas with high tofu consumption. Furthermore, several animal studies have suggested that diets containing certain vegetables, grains, or specific phytochemicals reduce the risks of experimentally induced colon cancer (Davis et al., 1999).

In the past several years, a number of chemical carcinogens such as 1, 2dimethylhydrazine (DMH), 2-amino-3methyl imidazole quinoline, methylnitrosurea, N-methyl-N-nitro- $\mathrm{N}$ nitrosoguanidine have been used to induce benign and malignant neoplasms in the colon of the rodents. These agents have provided a reasonably accurate experimental model of human colon cancer (Kamaleeswari et al., 2006). One such chemical DMH, a potent and complete carcinogen, has been reliably used to induce initiation and promotion steps of colon carcinogenesis in rodents. DMH and related compounds induce neoplasm specifically in colon of rat even after a single dose (Delage et al., 2005).Metabolic activation of DMH to highly reactive electrophiles (methyldiazonium ion) occurs in the liver and colon. However, the main target organ 
of $\mathrm{DMH}$ is the large intestine (Kamaleeswari et al., 2006).

The present study was conducted to determine the possible preventive effects of lifetime exposure to soybean on Dimethylhydrazine-induced colon tumors in male Sprague Dawley rats.

\section{Experimental Design}

This experiment was conducted on male Sprague-Dawley strain rats, weighing 80$100 \mathrm{~g}$. The rats were obtained from the breeding unit of the National Research Center in Cairo and maintained on commercial standard pellet diet purchased from Cairo Company for Oil\& Soaps. This diet consists of $20 \%$ casein, $15 \%$ corn oil, $55 \%$ corn starch, $5 \%$ salt mixture and $5 \%$ vitaminized starch. Dimethylhydrazine (DMH) (was obtained from Sigma Chemical Co). Soy powder (obtained from The Ministry of Agriculture).

40 mature male rats were divided equally into four groups of 10 animals each and treated for 16 weeks as follows: group I( Normal control group: was given the pellets of normal diet), groupII: (Soybean powder group: rats given diet contains $30 \%$ soybean powder), groupIII: (DMH- treated group was injected subcutaneously with $15 \mathrm{mg}$ DMH.2HC1 (Sigma, St Louis, MO) with DMH 20mg/kgwt weakly), groupIV: (DMH+ Soybean powder $30 \%$ - treated group rats injected by DMH and given a diet contains $30 \%$ soybean powder)

One week after the last DMH injection, all rats were euthanized, and the colon (caecum to anus) was taken, opened longitudinally, washed free of contents with ice-cold saline, and examined visually for tumors. The size, and number of all colon polyps were recorded. A representative section of each tumor was fixed in $10 \%$ neutral-buffered formalin. Sections $(5 \mu \mathrm{m})$ of paraffin-embedded tumors were stained with $\mathrm{H} \& \mathrm{E}$ for the histological analysis. For electron microscopic studies, small pieces of colon specimens were removed from all the studied rats, cut into small pieces (0.5$1 \mathrm{~mm}$ ) and immediately fixed in cold $4 \%$ glutaraldhyde in $0.2 \mathrm{M}$ cacodylate buffer $(\mathrm{ph}=7.2)$, and kept for $4 \mathrm{hrs}$ at $4{ }^{\circ} \mathrm{c}$ (Sabatini et al., 1963). After washing in the same buffer specimens were post-fixed in $1 \%$ osmium tetra-oxide in cacodylate buffer $(\mathrm{ph}=7.2)$ then embedded in plastic resin (Robenson et al.,1987). Semi thin sections ( $1 \mu$ in thickness) were cut using ultramicrotome, mounted on glass slides and stained with toluidine blue for light microscopic examination. Ultra-thin Sections were also cut, mounted on coated copper grids. Stained with uranyl acetate and lead citrate (Echlin, 1964) for transmission electron microscopic examination (Jeol JTM-1200EXII electron microscope).

\section{Results}

Colon Tumor Incidence: The incidence of colon tumours is the most reliable endpoint for evaluation of the chemopreventive effects of substances ( Perše and Cerar, 2011). In fig. ( $\left.1_{\mathrm{a}}\right)$, no 
macroscopically visible lesions occurred in the intestinal tract of the untreated control rats. The same picture was observed in rats received soybean powder. On the other hand rats treated with $\mathrm{DMH}$ developed grossly identifiable number of polypoid tumors in their colons (Fig. $1_{\mathrm{b}, \mathrm{c}}$ ) Meanwhile the number of colon tumors per individual in $\mathrm{DMH}$ treated animal has significantly decreased upon the effect of soybean powder treatment (Table1).

\section{Histopathological studies:}

The colon of control group displays the normal histological feature of (Figs. $2_{\mathrm{a}, \mathrm{b}}$.)The muscular wall is consequently thick and capable of powerful peristaltic activity. As in the rest of the gastrointestinal tract, the muscularis propria of the large intestine consists of inner circular and outer longitudinal layer (Fig. 2a the mucosa consists of cells of two types absorptive cells and mucoussecreting goblet cells, as seen in fig. $(2 \mathrm{~b})$. They are arranged in closely packed straight tubular glands (Fig. 2a ) an arrangement which greatly enhances the functional surface area. The colonic crypts in a property oriented section reach from the surface to the muscularis mucosa (Fig. $2 a$ ). The colon of soy powder treated rat group appeared to be more or less normal. Some changes can be illustrated in the regularity appearance of the epithelial cells lined up along the lumen with mild proliferation of the packed layer of the tubular glands forming the mucosa and submucosa layer (Fig. 2c). Also increased number of crypts with numerous goblet cells and absorptive cells (Figs. $2_{\mathrm{c}, \mathrm{d}}$ ) can be observed, the muscularis layer showing a normal appearance (Fig. 2 ). At the electron microscopic level, normal control colon section showed regularly shaped epithelial cells lined up along the lumen with small intercellular gaps, the regular shaped cells forming relatively structural glands between blood vessel and the central lumen (Fig. $3_{\mathrm{a}}$ ) among the mucosa layer two different cell types goblet cells were detected with their highly condensed nucleui, the cytoplasm is packed with rough endoplasmic reticulum and a few mitochondria (Fig. $3_{\mathrm{b}}$ ). In ultrastructure preparations the epithelial cells lined up along the lumen showed a normal appearance (Figs. $3_{\mathrm{c}, \mathrm{d}}$ ). Normal goblet cell and absorptive cell with normal mitochondria and normal cell junction were observed (Fig. $3_{d}$ ).

\section{Induction of cancer}

Rat colon treated with DMH only showed crowded glands which are irregular in shape and size these glands invaded the muscular layer (Fig $4_{\mathrm{a}}$ )some glands are of much large size and filled with necrotic debris (Fig 4a), glandular cells showed hyperchromatic nuclei (Fig $4_{b}$ ) these cells are infiltrated with inflammatory cells (Fig $4_{b}$ ). At the electron microscope level the colon showed abnormal appearance of cells, the absorptive cells showed numerous desmosomes(Fig.4c) 
mitochondria of different shapes, large number of swollen vacuolated mitochondria (Fig.4 $4_{d}$ ), some cells have swollen condensed mitochondria, most of the cells are vacuolated with different sizes of vacuoles (Fig. 4d) some of these vacuoles contained finally fibrillar materials, the goblet cells showed abnormal appearance of mucigen secretion, some of which have empty appearance, others showed edema appearance(Fig. 4d).

\section{Preventive effect of soybean powder}

Colon of rats treated with $\mathrm{DMH}+$ soybean powder showed different degrees of cell dysplasia with more crowded disorganized gland than normal, the cell proliferation generating tubular shapes more or less irregular or branched forming villi finger like projection lined by dysplastic lies directly on the muscularis mucosa and submucosa (Fig. 5a). the neoplastic epithelium characterized by loss of normal differentiation of epithelium and the irregular cells with hyperchromatic nuclei and mucin vacuoles were realized ( Fig. 5b) No evidence of necrotic debris or glands invaded in the muscular layer. At the electron microscope level, rat colon treated with DMH +soybean powder showing several abnormally shaped or immature cells of the goblet cells with their densely packed nuclei (Fig. 5c), the goblet cells contained large mucous vacuoles with small apical vesicles (Fig.5c), desquamated colonic epithelium with dilated intracellular space were observed (Fig.5c).
The cell junction showed interdigitation of lateral cell processes (Fig. $5_{\mathrm{d}}$ ).

\section{Discussion}

Cancer chemoprevention is a desirable and important facet of biomedical research which in addition to provide a practical approach to identify potential useful inhibitors of cancer development, also offers an opportunity to study the mechanism of carcinogenesis (Wattenberg, 1992). Higher plants, however, contains an extensive variety of compounds which are strong modifiers of chemical carcinogenesis (Shukla et al. 1999).

In the present study no macroscopically visible lesions occurred in the intestinal colon of the untreated control rats or in rats received soybean powder. On the other hand rats treated with $\mathrm{DMH}$ developed grossly identifiable number of polypoid tumors in their colon and the number of colon tumors per individual in DMH treated animal has significantly decreased upon the effect of soybean powder treatment.

The current data agree with the results reported by Messina (1999) who postulated that, many groups of researchers have suggested that the regular consumption of soybean is associated with the relatively lesser risk of different cancers in countries that include soybean in their diets. A number of soy components have been investigated for potential anticancer activity. Soybean contains 
several components with anticancer activity, such as, isoflavones, protease inhibitors, phytosterols, saponins, phenolic acids, and phytates. Most of the data support that predominantly isoflavones are responsible for the anticancer effects of soybean (Johnson, 2000). Based on the estrogenic activity of isoflavones, they can possibly be used for prevention and treatment of hormone dependent cancers (Adlercreutz, 2002). Rondini and Bennink (2012) demonstrated that black bean (BB) and soy flour (SF)-based diets inhibit azoxymethane (AOM)-induced colon cancer. They identify genes altered by carcinogen treatment in normalappearing colonic mucosa and those attenuated by bean feeding, they found that genes involved in the extracellular matrix and innate immunity were induced by AOM in all diets, but to a lower extent in bean-fed animals. This profile suggests beans inhibit colon carcinogenesis by modulating cellular kinetics and reducing inflammation, potentially by preserving mucosal barrier function.

In the histopathological studies the colon of control rat group displays the histological feature of normal colon. The colon of soy powder treated rat group appeared to be more or less normal. Some changes can be illustrated in the regularity appearance of the epithelial cells lined up along the lumen with mild proliferation of the packed layer of the tubular glands with increased number of crypts, numerous goblet cells and absorptive cells. At the electron microscopic level, normal control colon section showed regularly shaped epithelial cells, the cytoplasm is packed with rough endoplasmic reticulum with few mitochondria. In ultrastructure preparations the epithelial cells lined up along the lumen showed normal appearance.

These results may be attributed to the benefit effect of soy bean powder with its protein, fiber, and antioxidant content, the antioxidant ability have in vitro scavenging capabilities for reactive oxygen species. Cross et al. (2004) demonstrated that nutritional soy could indeed regulate synthesis and catabolism of 1, 25-D3 in the colon in such a manner that increased levels of the steroid hormone synthesized in colonic tissue. It is striking that this mechanism could become primarily activated by nutritional soy under hyperproliferative conditions in the colon. Indeed, such mechanism could be considered a perfect example of nutritional prevention of tumor progression that is most effective under premalignant conditions. The major phytoestrogen in soy and genistein is very effective in regulating 1, 25-D3 synthesis even after a single application under nonproliferative colonic conditions. This suggests that genistein may be the metabolite in dietary soy that regulates vitamin D synthesis in the colon. 
Wu (2003) indicated that soybean isoflavones may offer protection against a wide range of human conditions, including breast, bowel, prostate and other cancers, cardiovascular disease, brain dysfunction, alcohol abuse, osteoporosis and menopausal symptoms. Several mechanisms for their protective function have been proposed, although the exact mechanisms have not been identified. Soybean isoflavones have antioxidant activity, that may influence the production, metabolism and biological function of sexhormones, which may affect the synthesis and activity of intracellular enzymes, and may change growth factor action, malignant cell adhesion, proliferation, and differentiation. These factors alone or in some combination contribute protective functionality to human health.

Rat colon treated with DMH only showed crowded glands which are irregular in shape and size, these glands invaded the muscular layer, some glands showed large size and were filled with necrotic debris. At the electron microscope level the colon showed abnormal appearance of cells, mitochondria of different shapes, swollen vacuolated mitochondria, most of the cells contained different sizes of vacuoles.

These results are in agreement with the work done by ( Sengottuvelan et al.,

Low micrograph of rat group treated with DMH+soybean powder showed different degrees of cell dysplasia with more crowded disorganized glands than
2006), who reported that $\mathrm{DMH}$ is a colonspecific carcinogen, which is metabolically activated in the liver and then delivered to the colon via the blood stream or via bile as glucuronide conjugates. After further activation, it methylates DNA mainly at the $\mathrm{N}^{1}$ and $\mathrm{O}^{6}$-positions of guanine. DNA adduct formation is considered to be the initiating step in the formation of tumorigenesis. Rajeshkumar and Kuttan (2003), stated that cell proliferation plays an important role in multistage carcinogenesis with multiple genetic changes. Therefore, control of cell proliferation is important for cancer prevention. Mechanisms by which certain carcinogens which cause carcinogenesis is believed to be mediated by free radicals. Hydrazines and its derivatives, DMH and isoniazid, which can produce active oxygen species, have been shown to induce DNA damage process and carcinogenesis which can be abolished by free radical scavengers, also provide indirect evidence of the involvement of radicals in carcinogenesis. adenocarcinomas were those in which neoplastic cells had penetrated the muscularis mucosa to invade the submucosa or deeper layers.

normal, the cell proliferation generating tubular shapes more or less irregular or branched forming villi finger like projection lined by dysplastic lies directly on the 
muscularis mucosa and submucosa. At the electron microscope level, rat colon treated with DMH +soybean powder showing several abnormally shaped or immature cells.

Guo et al. ( 2003) reported that the protective effect of soy protein may have been due to a reduced cell proliferation in the colon, as the overall colon weight was lower in animals fed soy protein compared to those fed casein. The components of soy protein that may have provided the protective effect are not known. Dietary fiber has long been considered to reduce colon cancer development, soy protein may contain other forms of fiber which may have altered gut microflora and thereby reduces tumor cell growth.

Table (1): Effect of soybean products on DMH-induced colon tumors.

\begin{tabular}{|c|c|}
\hline Groups & $\begin{array}{c}\text { Mean no. of tumors per tumor-bearing rats } \\
\pm \mathrm{SE}\end{array}$ \\
\hline $\mathrm{DMH}$ & $31.25 \pm 1.5$ \\
\hline Soybean powder $+\mathrm{DMH}$ & $13.75 \pm 1.3$ \\
\hline
\end{tabular}




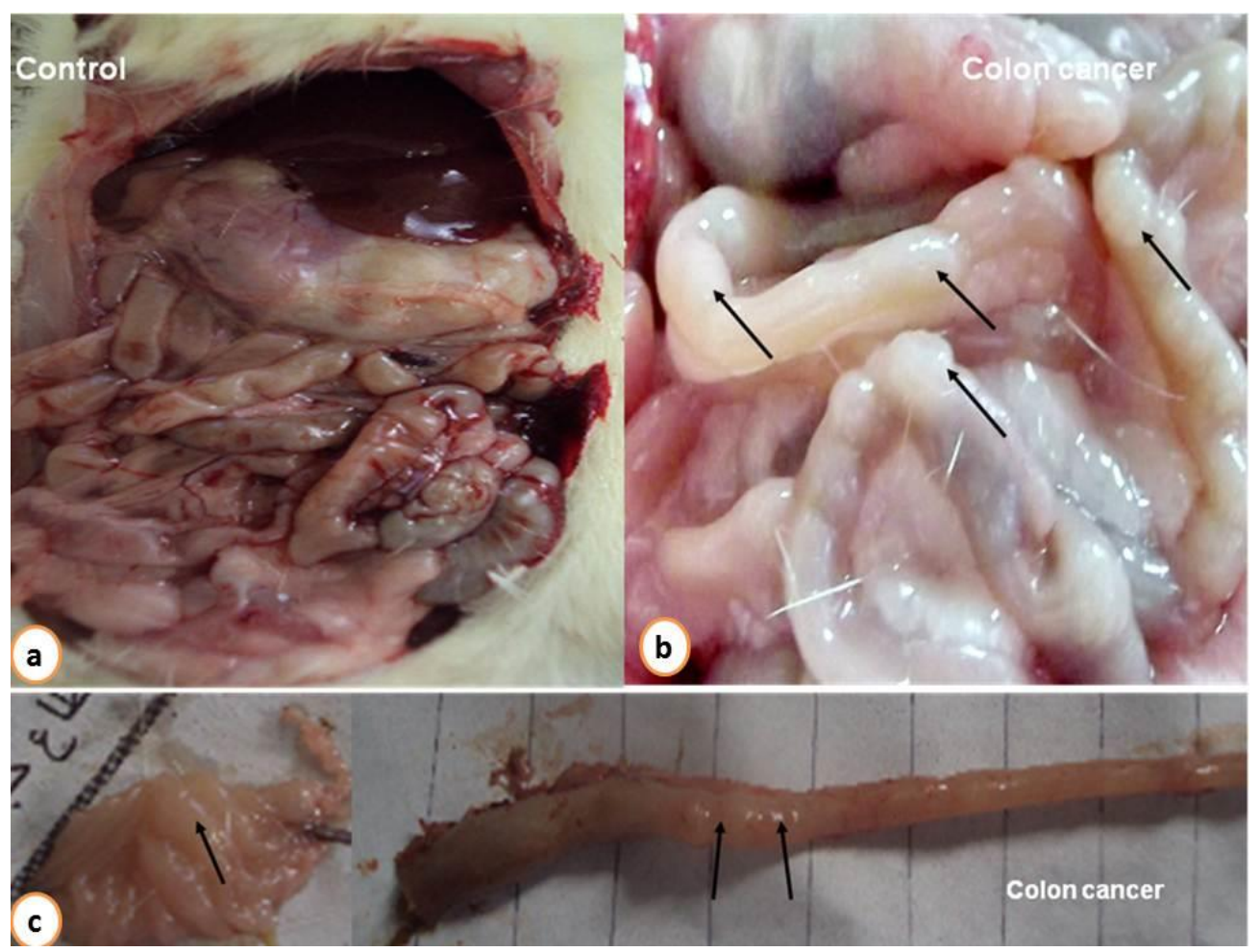

Fig. 1: The incidence of polypoid colon cancer tumor $(\uparrow)$

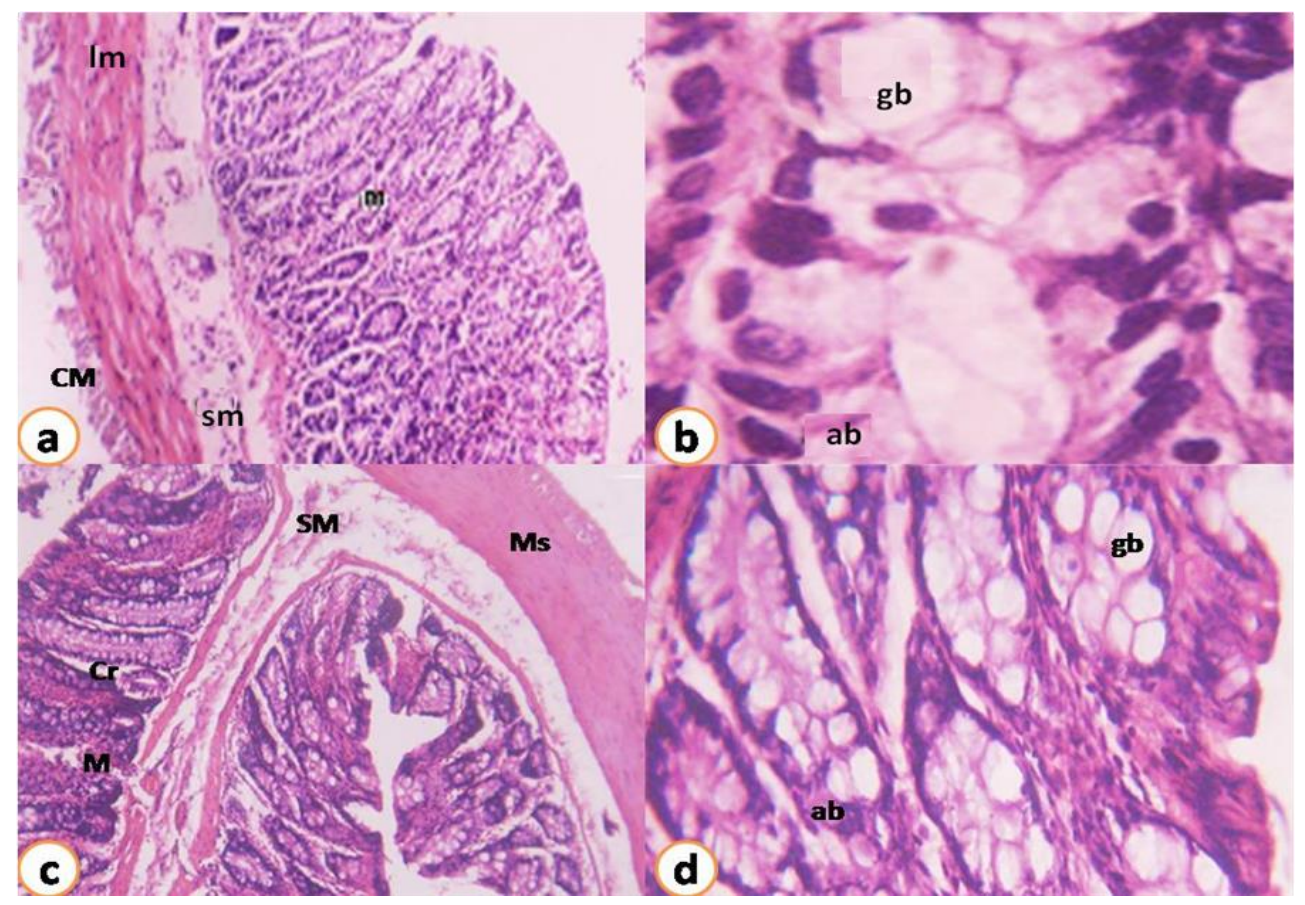

Fig. 2: (a) Photomicrograph of a section of control rat colon, showing circular muscular (CM), longitudinal muscular (IM), mucosa layer (M), submucosa (SM). X100 (H \&E) (b) Photomicrograph of a section of normal control colon, absorptive cells (ab) goblet cell (gb). X400 (H \&E) (c) Photomicrograph of a section of rat colon treated with soy powder showing normal architecture of mucosa layer (M) and submucasa (SM), crypts(cr) muscularis layers (MS). X 200(H\&E)(d) Higher magnification of fig. 2(c), goblet cells (gb) absorptive cells (ab). X400(H\&E 

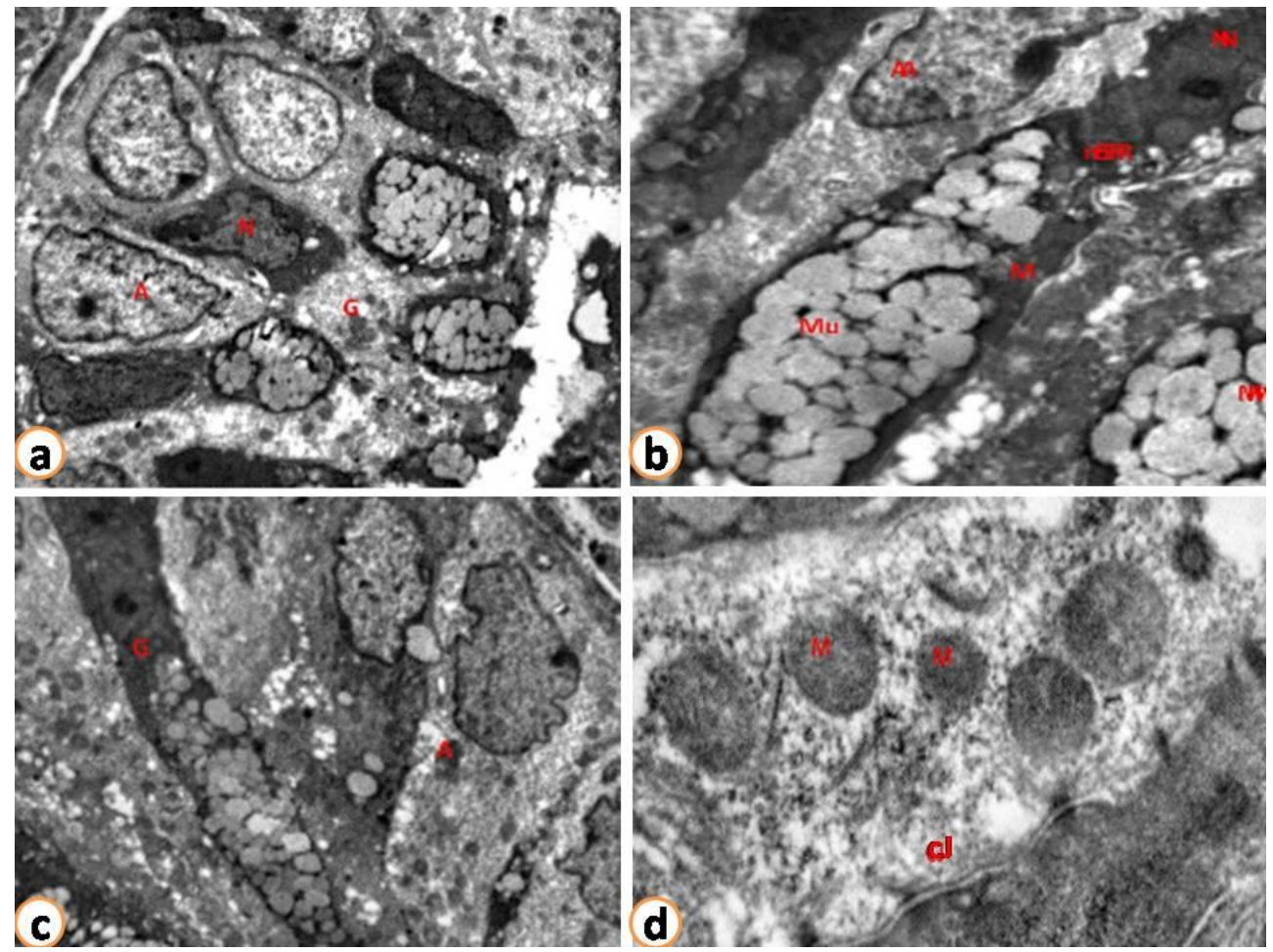

Fig.3(a) Electron micrograph of control rat colon, goblet cells $(\mathrm{G})$, condensed nucleus $(\mathrm{N})$, and absorptive cells (A). x4000 (b) High magnification of electron micrograph of control rat colon, showing condensed nucleus of the goblet cell(N), a few mitochondria $(\mathrm{M})$, Mucigen secretion $(\mathrm{Mu})$, columnar absorptive cell(A). x10000 (c) Electron micrograph of rat colon given soybean powder, showing goblet cells (G) and absorptive cells (A). $\quad$ x4000 (d) High magnification of electron micrograph of rat colon given soybean powder absorptive cell (A), mitochondria (M), cell junction (CJ). X10000

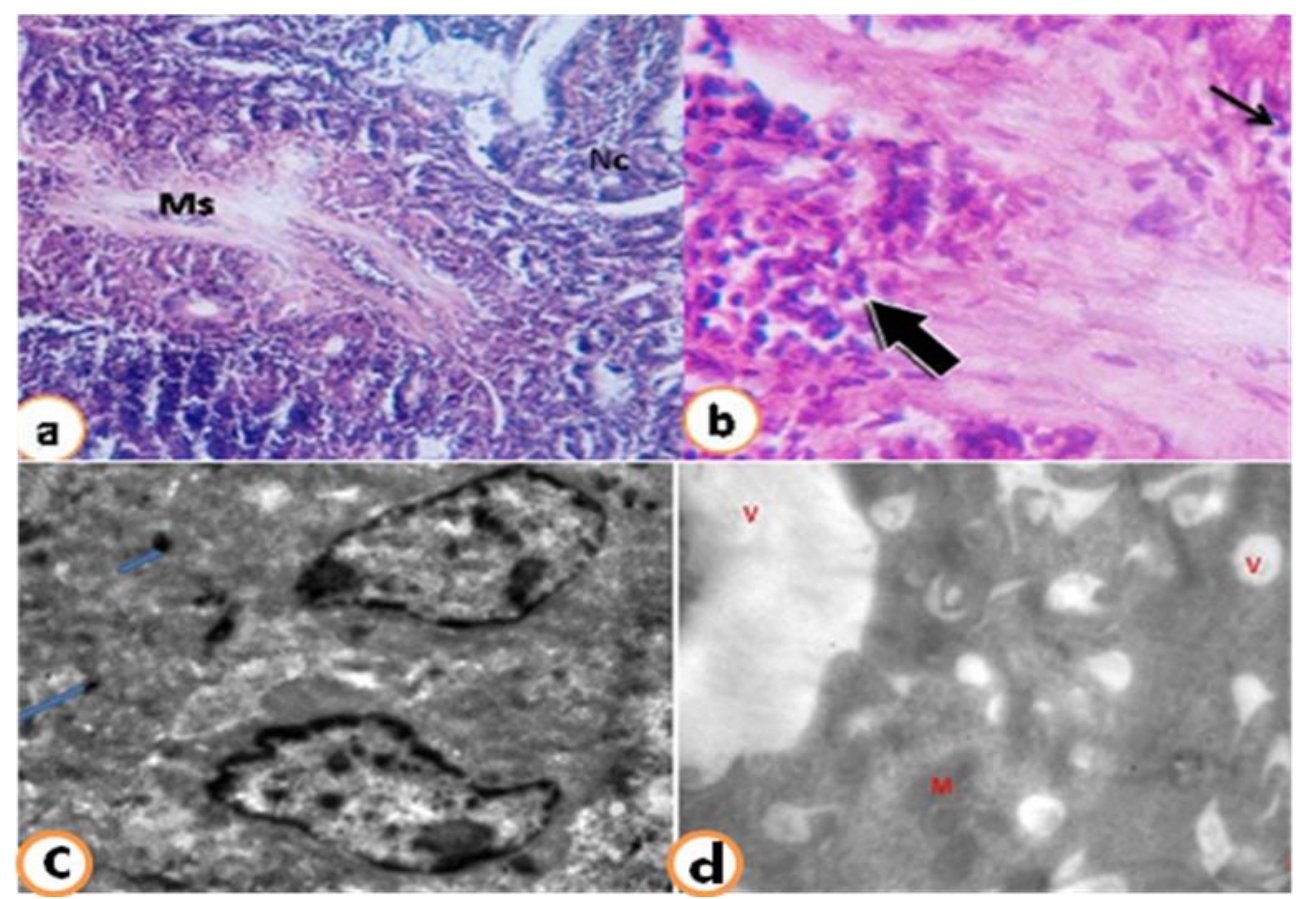

Fig.4: (a) Photomicrograph of rat colon treated with DMH, showing necrotic debris (Nc) degenerated muscular layer (Ms). x100(H\&E) (b) Higher magnification of rat colon section treated with DMH, hyperchromatic nuclei (arrow) inflammatory cells (Thick arrows). X400(H\&E) (c) Electron micrograph of rat colon treated with DMH only, numerous desmosomes (arrows). x10000 (d) Electron micrograph of rat colon treated with DMH only, showing cell vacuoles (v), mitochondria (M). x10000 


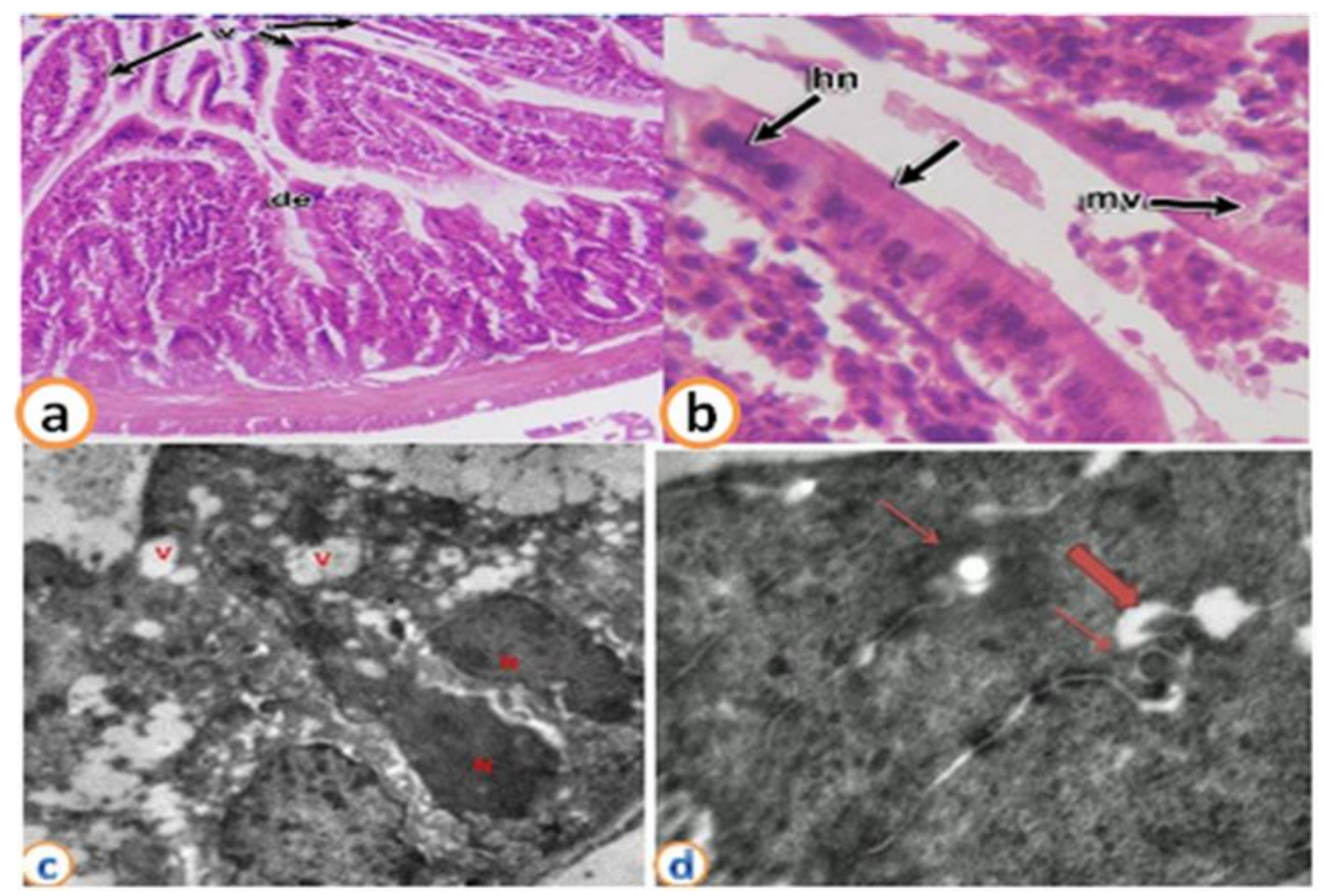

Fig.5(a) Photomicrograph of rat colon section treated with DMH+soybean powder villi finger like projection (V) and dysplastic (de) X100(H\&E) (b) Higher magnification of Fig.5(a) showing, neoplastic epithelium (arrow), hyperchromatic nuclei (hn), and mucin vacuoles (mv). X400(H\&E) (c) Electron micrograph of rat colon treated with DMH+soybean powder, nuclei (N), vacuoles (v). x10000 (d) Electron micrograph of rat colon treated with DMH+soybean powder, lateral cell processes (arrow), intercellular spaces (thick arrow). x50000

\section{References:}

Adlercreutz H (2002): Phyto-oestrogens and cancer. Lancet Oncol., 3:364-373.

Bond J H (2000): Polyp guideline: diagnosis. Am J Gastroenterol. , 95(11):3053-3063.

Boursi B and Arber N (2007): Current and future clinical strategies in colon cancer prevention and the emerging role of chemoprevention. Current Pharmaceutical Design, 13 (22): 2274-2282.

Chao A, Thun MJ and Connell CJ (2005): Meat consumption and risk of colorectal cancer. JAMA.,293:172-182.

Cross H S, Eniko K, Daniel L, Waltraud G, Herman A and James A H (2004): Phytoestrogens and Vitamin D Metabolism: A new concept for the prevention and therapy of colorectal, prostate, and mammary carcinomas. J. Nutr.,134: 1207-1212.

Davis M J, Bowey E A, Adlercreutz H, Rowland I $R$ and Rumshy P(1999): Effects of soy or rye supplementation of high-fat diets on colon tumor development in azoxymethane-treated rats.Carcinogenesis(Lond), 20: 927-931.

Delage B, Bairras C, Buaud B, Pallet V, and Cassand P. (2005): "A high-fat diet generates alterations in nuclear receptor expression: prevention by vitamin A and links with cyclooxygenase-2 and beta-catenin, International Journal of Cancer, 116: 839-846.

Echlin P (1964): Intra-cytoplasmic membranous inclusions in the blue-green alga, anacystis nidulans. Arch. Mikrobiol., 49: 267-274.

Guo JY, Li X, Browning JD and Lubahn DB (2003): Soy isoflavones reduce colon tumor incidence in wildtype and ER $\alpha$ KO mice. FASEB J., 17: 1203 - 1213.

Hakkak R , Korourian S, Shelnutt S R, Lensing S, Ronis M J J and Badger T M (2000): Diets containing whey protein or soy protein isolate protect against 7,12dimethylbenz(a)anthracene-induced mammary tumors in female rats. Cancer Epidemiol. Biomark. Prev., 9: 113117. 
Hoensch H P and Kirch W (2005): Potential role of flavonoids in the prevention of intestinal neoplasia A review of their mode of action and their clinical perspectives. International Journal of Gastrointestinal Cancer., 35(3): 187-195.

Jemal A, Ram C T, Taylor M, Asma G, Alicia S, Elizabeth W, Eric J F, and Michael J T (2004): Cancer Statistics.CA CancerJ Clin., 54(1): 8- 29

Johnson IT (2000): Anti-tumour Properties In Functional Foods. Woodhead Publishing, Cambridge, England., 141-162.

Kamaleeswari M, Deeptha K, Sengottuvelan M and Nalini N(2006): Effect of dietary caraway (Carum carvi L.) on aberrant crypt foci development, fecal steroids, and intestinal alkaline phosphatase activities in 1,2-dimethylhydrazineinduced colon carcinogenesis. Toxicology and Applied Pharmacology. , 214 (3): 290-296.

Lamartiniere CA (2000): Protection against breast cancer with genistein: a component of soy. Am J Clin Nutr., 71:1705-1707.

Levi F C, Pasche F L and Vecchia C L (2001): Dietary fibre and the risk of colorectal cancer. Eur. J. Cancer, 37:2091- 2096.

Messina M J (1999): Antitumor effect of soybean. Am. J. Clin. Nutr.,70: 439-450.

\section{Messina M, Persky VP and Barnes S (1994):}

Soy intake and cancer risk - a review of the in vitro and in vivo data. Nutr. Cancer ,21: 260-268.

Perse M and Cerar A (2011): Morphological and molecular in alterations in 1,2 Dimethylhydrazine and Azoxymethane Induced Colon Carcinogenesis Rats. Journal of Biomedicine and Biotechnology, 201: 473964-473978.

Rajeshkumar NV and Kuttan R (2003): Modulation of carcinogenic response and antioxidant enzymes of rats administered with 1,2dimethylhydrazine by picroliv.Cancer Lett., 191: 137-143.

Robinson A J, Barns G, Fraser K, Carpenter E. and Mercer A A (1987): Conservation and variation of orf virus genome.Virology, 157: 13-23.

Rondini E A and Bennink MR (2012): Microarray Analyses of Genes Differentially Expressed by Diet (Black Beans and Soy Flour) during Azoxymethane-Induced Colon Carcinogenesis in Rats. Journal of Nutrition and Metabolism, 2012: 351796 - 351803
Sabatini D, Bensch K, and Barrnett R (1963): Electron microscope methodology. J. Cell Biol., 17:19-58

Sengottuvelan M, Senthilkumar $\mathbf{R}$ and Nalini N(2006): Modulatory influence of dietary resveratrol during different phases of 1, 2dimethylhydrazine induced mucosal lipidperoxidation, antioxidant status and aberrant crypt foci development in rat colon carcinogenesis. Biochim. Biophys. acta., 1760:1175-1183.

Shukla Y, Singh A and Srivastava B (1992): Inhibition of carcinogen induced activity of carcinogen induced activity of $\gamma$-glutamyl transpeptidase by certain dietary constituents in mouse skin. Biomed. Environ. Sci., 12: 66-71.

Su S J, Yeh T M, Lei $\mathrm{H}$ Y and Chow $\mathbf{N}$ (2000): The potential of soybean foods as a chemoprevention approach for human urinary tract cancer. Clin. Cancer Res., 6: 230-236.

Watanabe S and Koessel S (1993): Colon cancer: an approach from molecular epidemiology. J. Epidemiol. , 3: 47-61.

Wattenberg LW (1992): Chemoprevention of cancer by naturally occurring and synthetic compounds. In: Cancer Chemoprevention. Arbor, A. London, P: 19-39.

Wu Q (2003): Purification and Antioxidant Activities of Soybean Isoflavones. B.S., Zhejiang University. The Department of Food Science.

Zaizen Y, Higuchi Y, Matsuo N, Shirabe K, Tokuda $\mathrm{H}$ and Takeshita M (2000): Antitumor effects of soybeans on the mammary tumor induction by $\mathrm{N}$-methyln-nitrosourea in F344 rats. Anticancer Res., 20: 1439-1444 


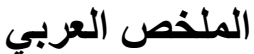

\section{شواهد على الدور الوقائي لقول الصويا ضد السرطان}

محمدالسيد زويل1 ، هناء فتحي واعر2 ، نعمات حنفي²، ايمان خاطر 1 ، هاله المنسي 3

1 كلية العلوم - قسم علم الحيو ان- جامعة بنها، 2 المركز القومي لبحوث وتكنولوجيا الأشعاع- هيئة الطاقة الذرية 3 كلية العلوم - جامعة عين شمس.

استهدفت هذه الدر اسة ايضاح الأمكانات المضادة للسرطان من فول الصويا ضد سرطان القولون وقد أجريت

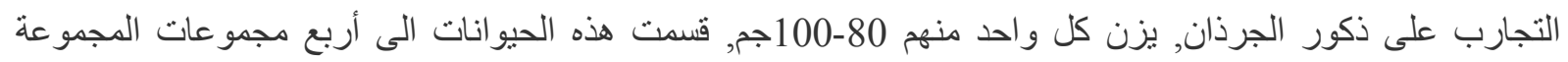

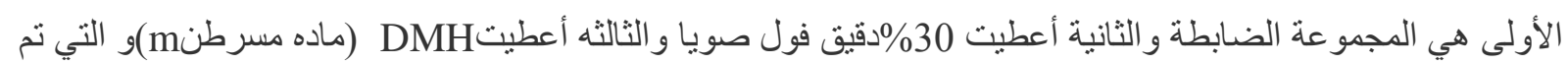
حلها في محلول ملحي وأعطيت الحيو انات حقنة بما يعادل 20مجم/كجم تحت الجلد مرة واحدة أسبو عيا لمدة 16 أسبوع

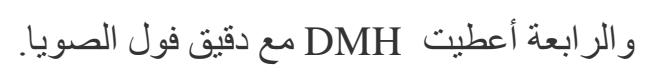

في نهاية التجربة نم ذبح جميع الجرذان ، وتم فحص القولون بالعين المجرده لحساب عدد الاورام في كل قولون وشملت الدر اسة أيضا دراسات هستولوجية الى جانب در اسات بالمجهر الألكتروني.

لم تظهر المجموعه المعاملة بفول الصويا أي أورام سرطانيه في القولون بينما أظهرت المجموعة المعاملة ب DMH

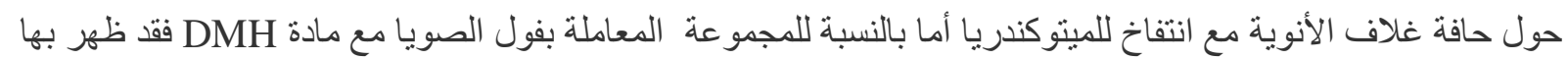
تحسن ملحوظ مع وجود القليل من التغيرات الهستولوجية.

الاستتتاج : في ضوء النتائج التي تم الحصول عليها من هذه الدراسة أنه من الواضح أن فول الصويا يمكن أن يظهر تأثير وقائي ضد سرطان القولون. 